\title{
Influence of digitalization upon formation of corporate strategy and new business models of modern organizations
}

\author{
Raisya Akmaeva ${ }^{1, *}$, Ravil Arykbaev ${ }^{1}$, Nelli Epifanova ${ }^{2}$, and Edvard Glinchevskiy ${ }^{1}$ \\ ${ }^{1}$ Astrakhan State University, Tatischev Str., 20a, 414056 Astrakhan, Russia \\ ${ }^{2}$ Caspian Pipeline Consortium, Kuibyshev Str., 62, 414056 Astrakhan, Russia
}

\begin{abstract}
This paper asserts that the issue of change of power in a corporate management configuration is quite urgent; it emphasizes that corporate management should identify the right combination of social interests and corporate business interests within the context of social, economic, and political processes currently taking place in Russia. The pandemic and digitalization exert a profound influence upon those processes; the paper states the fact that the Russian practice of corporate management - how decisions are made and how their execution is controlled - is characterized with a low quality, owing to the practice of "manual management" that prevails at all the hierarchical levels. The main idea of this article is that Russian managers should gradually substitute the traditional hierarchy with a "natural" one, when one's authority depends not on their official position, but on their contribution to work, when special emphasis is placed on selfcontrol, on establishment of a horizontal control system based on the Agile approach. Managers ought to realize that they should adopt new business models by integrating cutting-edge technologies (digitalization and other forms of work) in all the aspects of their corporate business activities.
\end{abstract}

\section{Introduction}

The world will undergo substantial changes in the post-coronavirus era, and the national economy will endure a heavier recession. Yet, the main issue of corporate management in Russia will remain as urgent as today: the model of efficient management of any corporation must be determined, first and foremost, with such top-priority factors as orientation towards social aspects related to a complete unleash of corporate human resources' intellectual potential, stimulation of processes of self-organization and creativity; flexibility of internal mechanisms of corporate management and its compliance with the adopted strategy; adaptability and sensibility to permanent changes in the external environment [1]. Hence, assessment of impact exerted by digitalization upon the formation of corporate strategies and new business models of present-day corporations is quite a topical issue. 


\section{Materials and Methods}

The paper applies research methods of economic, historic, and statistical analysis; comparison and analogies; the empiric approach in the development of social and economic processes in Russia in general and in Astrakhan Region in particular. Findings of field researches conducted by Astrakhan Region's scholars have been used as empiric data.

\section{Results and Discussion}

The most essential issue of corporate management that is still urgent in present-day Russia concerns change of power in a corporate management configuration. Should it be referred to the system of management, to its workforce, or should it be addressed to business owners, who hold the control packet of shares? What configuration should the workforce and particular members of staff be related to? Obviously, the main role in protection of rights and interests of all the participants is played by managers, who ought to identify the right combination of social interests and corporate business interests within the context of social, economic, and political processes that are currently taking place in Russia. The pandemic and digitalization exert a profound influence upon those processes. In our view, the issue of correlation between corporate centers of power (who plays the main role - managers or owners?) is becoming pointless, since Russian business owners and managers are still the same people. A well-known disadvantage of being both an owner and a top manager is absence of any external control of a General Manager's activities and thereby frequent violations of the workforce's rights.

Earlier findings gained by the Russian Bureau of Economic Analysis (BEA) confirm that most frequently, extra-large packets of shares in the Russian industries were held by less efficient categories of owners [2, p. 112]. Those companies whose control packets of shares were held by their managers proved to be more efficient upon their privatization, e.g. Severstal, Cherkizovo, etc.

At the current stage of development, stakeholders and top managers are equally interested in maintaining their businesses' competitiveness by mastering modern digital technologies and management innovations. Besides owners-stakeholders and top managers, who have a real power at Russian enterprises, other stakeholders (the regional authorities, the public, consumers, suppliers, and investors) have some authority as well. One should consider with interests of such a powerful stakeholder as the state, which ought to act as a guarantor of compliance with rules of economic behavior, not as an active economic subject. Specific features of the Russian national system of corporate management, which reflect both its development stages and the national mentality, quite often result in the fact that actions performed by a number of representatives of Russian state interests are based on their personal (or affiliated with other people) interests and tasks, which can influence corporate development negatively.

An increasing number of business representatives begin to realize that their main common goal (mission) is not only gaining profits, since an organization is an open system and it can survive only provided it meets one's external needs, whereas making profits is a company's internal problem. A business goal (mission) should include not only profits, but also social responsibility, which may be defined as a company's commitments to protect and enhance the social wealth considering with its own interests at the same time [3].

A manager's target interest is efficient application of capitals both at present and in the future, as well as sustainable revenues independently on the capital origin (be it their own or loan capital). Disagreement between managers' and owners' interests may only be due to their different horizons: a typical manager has a short-term vision, while an owner tends to regard their business in a longer-term run. In addition, the problem of the field of activities 
is more acute for a manager (owing to their professional preferences, since a manager is more interested in a growing scale which their increased personal authorities provide), while an owner is more interested in a growing enterprise value.

The developing nature of management activities also requires appropriate changes owing to changing conditions of business activities in the present-day crisis economy; it concerns especially the Russian practice of corporate management - how decisions are made and how their execution is controlled. It is well-known that Boards of Directors of Russian corporations do not cope with their functions; their level of management is low owing to the practice of "manual management" widely spread at all the levels in Russia [1].

Russian managers are mostly autocrats, and the very system of management is of authoritarian nature. One could agree with I. Adizes that Russian managers have no time to get used to present-day realities, to say nothing of changing actively. Such factors as unjust egalitarianism, nepotism, and corruption hamper their adaptation. Post-communistic Russia inherited not only the authoritarian style of management, but also fear of chiefs and authorities, even though such qualities as good education, erudition, creativity, and enterprise are real features of Russian managers [4, p. 40].

The world's best general managers, according to the ranking published in Harvard Business Review - Russia, state unanimously that success is provided mostly by a team; it is impossible to manage in a strictly centralized way, so a flat structure is essential; the most important thing in a General Manager's activities is to motivate people and sustain their team spirit, with a large number of staff members having the right to make decisions. Actually, the best managers have confirmed the importance of processes and tendencies, which have already emerged as a response to current changes in the world economy, in practice: (1) the end of the authoritarian style of management, since one chief cannot assess all the risks in the chaos of non-stop changes (so well-agreed actions of a team are necessary); (2) the end of a hierarchy, as systems fully denying it are developing - those are ecosystems, holacracy, network organizations, flat structures, and the agile methodology; (3) the force of team spirit, which helps tackle complicated tasks by developing interaction between teams and units, disregarding internal organizational boundaries [5, p. 13-18].

These tendencies coincide with the 25 large-scale tasks of management in the 21 st century listed in the concept "Management 2.0: New Version for New Age" [6]. The first and foremost task is to set high goals that should aim to tackle socially demanded and noble tasks (not to maximize profits, as it is now). A second task is to adopt the idea of corporate responsibility: management of the future ought to consider with interests of not only its top managers and stakeholders, but also its workforce and local communities, i.e. be sensitive to social needs in general. A third task implies that businesses of the future should easily adapt to any new conditions, provide a favorable environment for their employees and set high goals for them, develop innovations continuously, be socially responsible, and gain new knowledge in various fields. A fourth task is to reject the traditional hierarchy: one should substitute the traditional organizational pyramid with a "natural" hierarchy, which implies that one's status and authority depend not on their official position, but on their contribution to work.

A little more than 10 years have passed, and cutting-edge companies are already implementing these revolutionary ideas in practice; they adopt management innovations actively and introduce the most modern management techniques (agile, holacracy, etc.). Many Russian managers not only set socially demanded and noble goals for their companies; not only do they try to consider with their stakeholders' and top managers' interests, but also with their employees' and local communities' needs so as to gradually substitute the traditional hierarchy with a "natural" one, when one's authority comes from one's contribution to work (not from one's official position in that hierarchy), when everyone's 
self-control is of top priority, when a control system is applied horizontally, with one's colleagues' opinions (as the agile approach advises) of top importance [7].

All the managers agree that only digital transformation can give them a new chance to eliminate Russia's technological backwardness. Digitalization of economy is becoming of top priority for not only large Russian corporations, but also for small businesses, which requires a far wider application of new digital tools by Russian companies: cloud computing, 3D printing, the Internet of Things tools, virtual and augmented reality, Big Data, the blockchain technology, high-performance platforms to store and process data (such as $\mathrm{S} / 4$ HANA), etc.

Many industrial corporations are already optimizing their business models and production based on digitalization. Their range includes not only Sber, but also KamAZ, Petrozavodskmash, Kalashnikov, etc. In particular, KamAZ has already implemented automatic planning based on an ERP system; it has developed a production monitoring and operational management system; it interacts with its clients based on the SAP Hybris Cloud for Customer cloud platform; it applies almost 900 robots. As for Petrozavodskmash, thanks to its complex digitalization, it monitors manufacturing of particular details and components; one can easily see whether their quantity is sufficient to manufacture this or that product, how busy employees are at each stage of the production process; one can also obtain information related to planned and actual self-cost, which helps apply a more flexible approach to management of the entire enterprise [8]. One should note that a number of large corporations that have the necessary resources are already introducing expensive digital technologies, such as SAP/4 HANA (Severstal, the Alcohol Siberian Group, Cherkizovo, etc.). Nevertheless, other large companies assume a let-us-wait-and-see position; thus, they risk losing their competitiveness. As for small companies, they do not even dream about digitalization owing to their insufficient assets and resources, except for startups, which were lucky to find their niches at the market of digital innovations.

Besides the current pandemic, an incredibly high growth of technological modernization is becoming a new tendency. That was the response given by over $72 \%$ of top managers of the world's 500 large companies, when the Fortune conducted its 2017 survey [8]. In our opinion, technological innovations are the key to new business models, new markets, and new growth opportunities for Russian corporations.

Erased boundaries between industries are becoming an essential trend. Here are examples of how digital transformations require reconsideration of business models and diversification of activities: the Russian Post has become a retail bank, while Rostelecom has established a partnership with SAP to provide services in financial transactions, transformation into a universal supplier of cloud-based business solutions together with other telecommunication companies [9].

Thanks to Big Data technologies and information related to its previous purchases, Rostselmash has introduced a SAP-based client-oriented approach and automated its dealers' workstations; as a result, the company has developed a unique strategy oriented towards a particular client, being aware of what that client needs. Production of unmanned KamAZ trucks equipped with machine vision has already been planned for 2025, with intellectual transport systems to control them. The degree of automation and robotization at Cherkizovo, which manufactures summer sausages, is also impressive.

Large corporations are adopting SAP/4 HANA, which is a more progressive platform of new generation, successfully to automate their business processes compared with ERP. Severstal presented its report "SAP/4 HANA May Also Be Agile" at the forum "SAP NOW online" in April 2020. Severstal provides a good example as a company that implements digital projects regularly, with SAP/4 HANA becoming its digital heart. Therefore, digital transformation results in changing business models owing to introduction of breakthrough technologies into all the aspects of business activities. 
Large companies should consider experience gained by small innovative enterprises, which now adapt and customize easily to meet their consumers' new individualized needs, since customization is becoming a new trend of the objective reality [10]. Makers (i.e. people involved in small-scale inventions, or making) can create highly customized products as fast as standard ones, with their costs remaining the same; they can manufacture self-developed products in small quantities and with a high quality thanks to application of digital cloud technologies in their startups. A. Auzan states that it will be possible to produce a lot of either 10 , or 1 million units at high-capacity facilities, with logistic costs making the only difference [10].

\section{Conclusions}

Therefore, digital innovations and new organizational forms of works such as agile, holacracy, and formation of open ecosystems for consumers, innovators, and partners of modern efficient organizations are becoming a key to new strategies and business models, new markets and new opportunities of economic growth.

The identified tendencies and challenges set the problem of competitiveness in a new way. Present-day ecosystems must change as fast as their external environment; digital tools must be introduced by each member of staff on a daily basis, as they make manufacturing of many products cheaper and easier.

In present-day efficient companies, which are involved in digital transformation and which implement new organizational forms such as Agile, annual planning and budgeting cycles are substituted with shorter ones. Practicing managers applying the flexible Agile technology are well-aware of the fact that an annual cycle restrains innovations and that a consumer needs frequent changes represented by cutting-edge ideas. Elon Musk states that approximately 20 enhancements are implemented into Model S every week [11, p. 59]. Thus, new development strategies must be updated more frequently under conditions of digital transformation; they ought to consider application of digital tools, especially in the field of the Industrial Internet of Things and augmented reality, which will influence all the spheres of economy by changing the processes of education, decision-making, and interaction [12, p. 30].

In its turn, an obligatory condition to implement digital innovations successfully is new organizational forms of corporate ecosystems which unleash the staff's potential in its striving to create values for clients and realize its opportunities to develop as active entrepreneurs, which set everyone free to make their dreams come true [13, p. 54]. For Russian companies, the current coronavirus pandemic is a good reason to consider their renewal and update their business models.

Therefore, Russian companies should digitalize their activities and create their own ecosystems; a number of companies (Agrosignal, the Internet of Things Association, Rostelecom, Farvater, etc.) are already doing that. For instance, the Russian agriculture is being digitalized as a part of the general system of economy digitalization; in the future, it is planning to create platform ecosystems. There are already quite many organizations that offer business-oriented digital solutions in various fields: CodLix, Agrosignal, etc. In other words, there is a real supply of such solutions; yet, demand for those digital solutions is still rather low. According to a special survey conducted by the Internet of Things Association, the main factor that hampers introduction of digital innovations is absence of specialists who have completed at least a primary training program to understand digital tools.

In our opinion, the most essential task for practicing managers is to search and select particular digital projects to implement in their organizations based on efficient application of those projects in other companies. The main source of that information is the Internet, as well as webinars and seminars delivered by special professional organizations such as the 
Internet of Things Association established at the initiative of the Bauman Moscow State Technical University and the Internet Initiatives Development Fund, as well as by other similar associations established by the Higher School of Economics — National Research University, Peter the Great St. Petersburg Polytechnic University, etc. Managers do not have a full list of such professional organizations that might aid them; if there were such lists, it would save much time for searching the relevant information related to digital tools that might be implemented in practice. In our opinion, the legal authorities could make a decision to create self-regulated organizations in the sphere of digital transformation, which would have all the necessary information to share with managers. Joint efficient actions by corporate management and a special state information system to search and select efficient and relatively inexpensive digital projects to implement in Russian companies could make it possible to cope with this task. In this case, one cannot get along without legal authorities. This idea was expressed at the Marathon of Ideas arranged by the Agency for Strategic Initiatives. The appropriate units and departments of branch ministries and agencies are supposed to create that information system, which would include information about successful implementation of digital innovations at particular enterprises and in particular industries, similar to Bureaus of Scientific and Technical Information (BTI) in the Soviet era. Soviet enterprises used to receive BTI Bulletins about various innovations regularly. One could apply the Soviet experience and develop a system to collect the relevant information in various industries and regions. Support of the state represented by the Ministry of Economic Development and its regional units is necessary to promote this information for companies and corporations.

Nowadays Agrosignal acts as a guide for agricultural enterprises at its own initiative; it offers relatively inexpensive digital solutions to agricultural companies upon their requests. Besides solutions that it developed itself, it offers them solutions developed by other organizations and implemented in Russia successfully. The state represented by the Ministry of Economic Development and its regional units should contribute to active promotion of this information.

\section{References}

1. R. I. Akmaeva, Development of Efficient Management at Modern Russia's Industrial Enterprises (2007)

2. R. I. Kapeliushnikov, N. Demina, Russian Journal of Management, 3(3), 110 (2005)

3. A. E. Khachaturov, Management in Russia and Abroad, 2, 10 (2004)

4. I. Adizes, HBR - Russia, 6 (2017)

5. R. I. Akmaeva, Bulletin of Dagestan State University, Ser. 3 Social Sciences, 32(4), 13 (2017)

6. Management 2.0: New Version for New Age, HBR - Russia, 91 (2009)

7. D. Rigby, J. Sutherland, H. Takeuchi, HBR - Russia, 39 (2016)

8. M. Belzer, Digitalization of Industry: a Fashionable Trend or a Necessary Condition to Maintain Competitiveness? https://promdevelop.ru/

9. S. Ragimova, Forbes Brand Voice, http://www.forbes.ru/

10. A. Auzan, HBR - Russia, 81 (2016)

11. D. Rigby, J. Sutherland, A. Noble, HBR - Russia, 59 (2018)

12. M. Porter, J. Heppelmann, HBR - Russia, 30 (2017)

13. G. Hamel, M. Zanini, HBR - Russia, 47 (2018) 